\title{
Simultaneous occurrence of brain tumor and myeloradiculopathy in schistosomiasis mansoni: case report
}

\author{
Ocorrência simultânea de tumor cerebral e mielorradiculopatia na \\ esquistossomose mansoni: relato de caso
}

\author{
José Roberto Lambertucci ${ }^{1}$, Silvio Roberto Souza-Pereira ${ }^{2}$ \\ and Tânia Antunes Carvalho ${ }^{1}$
}

\begin{abstract}
Simultaneous occurrence of brain tumor and myeloradiculopathy in cases of Manson's schistosomiasis have only rarely been described. We report the case of a 38-year-old man who developed seizures during a trip to Puerto Rico and in whom a brain tumor was diagnosed by magnetic resonance imaging: brain biopsy revealed the diagnosis of schistosomiasis. He was transferred to a hospital in the United States and, during hospitalization, he developed sudden paraplegia. The diagnosis of myeloradiculopathy was confirmed at that time. He was administered praziquantel and steroids. The brain tumor disappeared, but the patient was left with paraplegia and fecal and urinary dysfunction. He has now been followed up in Brazil for one year, and his clinical state, imaging examinations and laboratory tests are presented here.
\end{abstract}

Key-words: Brain tumor. Neuroschistosomiasis. Myeloradiculopathy.

\section{RESUMO}

Tem sido descrita, raramente, na esquistossomose mansônica, a ocorrência simultânea de tumor cerebral e mielorradiculopatia. Relatamos aqui o caso de um homem de 38 anos que desenvolveu convulsões, durante viagem a Porto Rico, e um tumor cerebral foi diagnosticado à ressonância magnética: a biópsia do cérebro revelou o diagnóstico de esquistossomose. Ele foi transferido para hospital na América do Norte e durante a hospitalização desenvolveu súbita paraplegia. 0 diagnóstico de mielorradiculopatia foi confirmado na ocasião. Ele recebeu praziquantel e esteróides. 0 tumor cerebral desapareceu, mas o paciente permaneceu com paraplegia, disfunção urinária e fecal. Ele tem sido acompanhado no Brasil no último ano e o seu estado clínico, os métodos de imagem e os exames de laboratório são apresentados aqui.

Palavras-chaves: Tumor cerebral. Neuroesquistossomose. Mielorradiculopatia.

Neurological involvement is associated with infection by the three main species of Schistosoma (Schistosoma mansoni, Schistosoma japonicum and Schistosoma baematobium $)^{129111321}$. Although myeloradiculopathy is the most common neurological complication of Schistosoma mansoni infection, the prevalence of cerebral and spinal cord schistosomiasis is unknown. Neuroschistosomiasis is probably underdiagnosed, underestimated and underreported ${ }^{812} 14$.

Severe neurological involvement has been described during the early post-infective stage in non-immune patients ${ }^{1015}$. Acute encephalitis and cerebral vasculitis have been reported during primary infection with Schistosoma mansoni ${ }^{928}$. Asymptomatic neuroschistosomiasis appears to be more frequent in association

1. Graduation Course in Health Science: Infectology and Tropical Medicine, Faculty of Medicine, Federal University of Minas Gerais, Belo Horizonte, MG, Brazil. 2. Department of Neurology, Faculty of Medicine, Federal University of Minas Gerais, MG, Brazil. Address to: Dr. José Roberto Lambertucci. Faculdade de Medicina/UFMG, Av. Alfredo Balena, 190 30130-100 Belo Horizonte, MG, Brazil.

Tel: $55313409-9820$.

e-mail: lamber@uai.com.br

Received in 20/03/2009

Accepted in 20/05/2009 with the more severe chronic forms of Schistosoma mansoni. A Brazilian autopsy case series revealed scattered ova of Schistosoma mansoni in 25\% of the brains of patients (without neurological deficit) who died due to hepatosplenic schistosomiasis ${ }^{24}$.

Schistosoma mansoni can also cause a brain tumor-like syndrome due to slowly expanding cerebral and cerebellar lesions ${ }^{46151823242627}$.

Schistosomal myeloradiculopathy is the most severe and disabling ectopic form of Schistosoma mansoni infection ${ }^{11} 1317$. The prevalence of schistosomal myeloradiculopathy at centers in Brazil and Africa that specialize in attending patients with nontraumatic myelopathy is around $5 \%^{322}{ }^{29}$. The initial signs and symptoms of the disease include lumbar and/or lower limb pain, paraparesis, urinary and intestinal dysfunctions and impotence in men ${ }^{16}$. The cerebrospinal fluid of schistosomal myeloradiculopathy patients shows increased protein concentrations and increased numbers of mononuclear cells in $90 \%$ of the cases; eosinophils have been reported in $40 \%{ }^{22324}$. The use of magnetic resonance imaging is particularly useful for diagnosing schistosomal myeloradiculopathy ${ }^{15}$. It remains essential to rule out other myelopathies and systemic diseases. Early diagnosis and treatment with steroids and schistosomicides provide a cure for most 
patients, whereas delayed treatment can result in irreversible physical disabilities or death ${ }^{3143132}$.

To our knowledge, there have been only two previous reports of simultaneous brain and spinal cord involvement in cases of Manson's schistosomiasis. Ruffino et al ${ }^{28}$ presented the case of a young woman with cerebral and spinal cord involvement who improved after treatment for schistosomiasis, but they did not present any diagnostic imaging or brain biopsy. Artal et al ${ }^{2}$ presented the case of a 65-year-old male patient in whom the diagnosis was confirmed by brain biopsy.

Here, we present the case of a patient with simultaneous brain and spinal cord lesions, with a documented one-year follow-up after the first diagnosis.

\section{CASE REPORT}

A 38-year-old white male American citizen who had been living in Brazil for the preceding 10 years developed seizures during a trip to Puerto Rico. He and his Brazilian wife had a long history of traveling around the world. He was admitted to hospital, and gadolinium-enhanced magnetic resonance imaging of the brain showed a large hyperintense area in the right frontal-parietal lobe (Figure 1). A brain biopsy revealed the diagnosis of Schistosoma mansoni infection (Figure 2). After diagnosis, he was treated for schistosomiasis with praziquantel and was started on steroids (dexamethasone 4mg orally every 6 hours) for two weeks. He was then transferred to a hospital in the United States. During his stay in the United States, he developed lower limb weakness, loss of sensation and flaccid paralysis. There was also urinary retention and he did intermittent catheterization by himself. He presented bowel incontinence and had no sensation during the act of defecation. There was no movement or any sensation in the lower limbs and extending upwards almost to just below the rib cage. Magnetic resonance imaging of the spinal cord revealed a hyperintense signal from T1 to T11 (Figure 3).

He was treated for seizures with hydantoin, and received praziquantel and steroids again during the second hospitalization. Treatment with steroids was given for two weeks. No improvement was noted during treatment. Four months later, he came back to Brazil and, since then, he has been followed up at the Infectious Diseases Unit of the Federal University of Minas Gerais. In our hospital, he was again started on steroids (prednisone, 80mg, single dose, daily) for two months, without improvement.

To rule out other causes of transverse myelitis, the following tests were performed: clinical and neurological examination, blood cell count, fasting glucose, serum cyanocobalamin, lupus anticoagulant, antinuclear antibodies, venereal diseases research laboratory (VDRL), hepatitis B surface antigen, antibodies for hepatitis B surface antigen, antibodies for hepatitis B core antigen, IgM antibodies for cytomegalovirus and herpes simplex virus, antibodies for human T lymphotropic virus types 1 and 2, and antibodies for human immunodeficiency virus (HIV). Abdominal ultrasound did not find any evidence of periportal fibrosis. Biochemical and cytomorphological tests on cerebrospinal fluid specimens obtained by lumbar puncture were also performed.

He was left with paraplegia, fecal and urinary retention and flaccid paralysis of the lower limbs (Figure 4). No sequelae of the brain lesion are apparent; the patient is alert, oriented and good-humored, in spite of the limitations caused by the spinal cord involvement. A magnetic resonance image of the brain, 12 months after the brain biopsy, revealed only the place where the biopsy was performed (Figure 1). A magnetic resonance image of the spinal cord showed an extensive thoracic area of spinal cord thinning (Figure 3). He is undergoing a program of physiotherapy and psychotherapy.

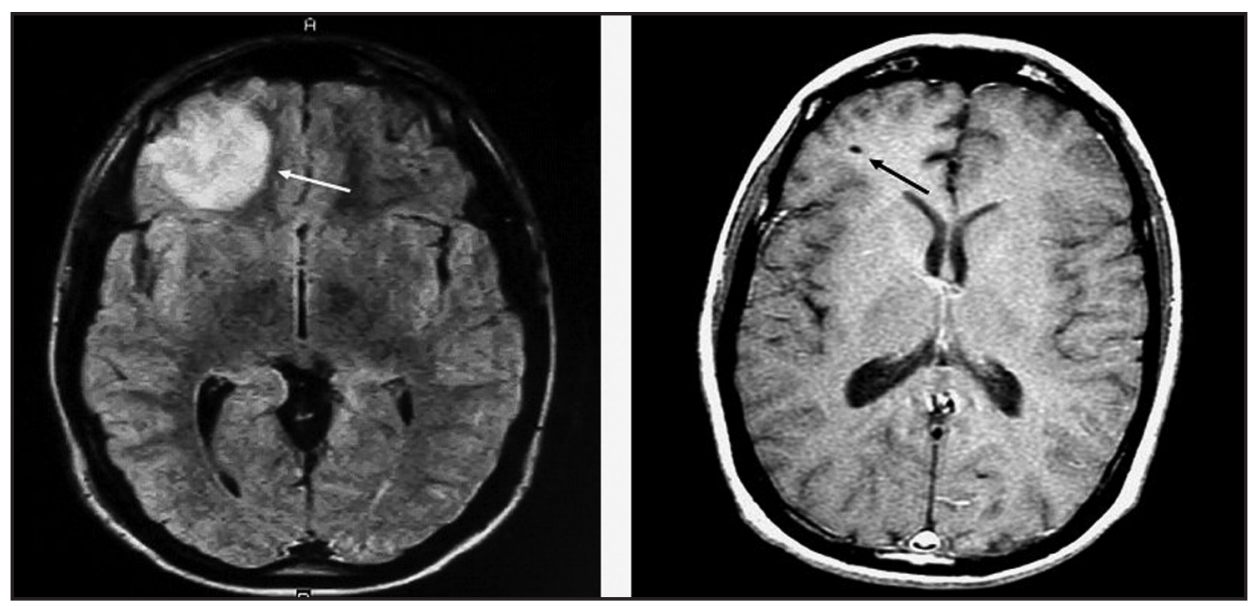

FIGURE 1

Magnetic resonance of the brain tumor (white arrow) of a patient with schistosomiasis mansoni before treatment (on the left) and one year after treatment (on the right - black arrow points the hole left by the needle biopsy). 


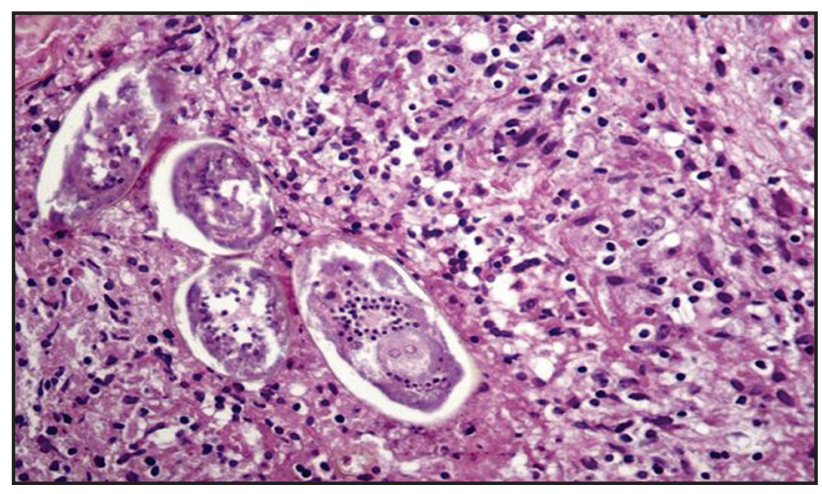

FIGURE 2

Brain biopsy showing 4 eggs of Schistosoma mansoni.

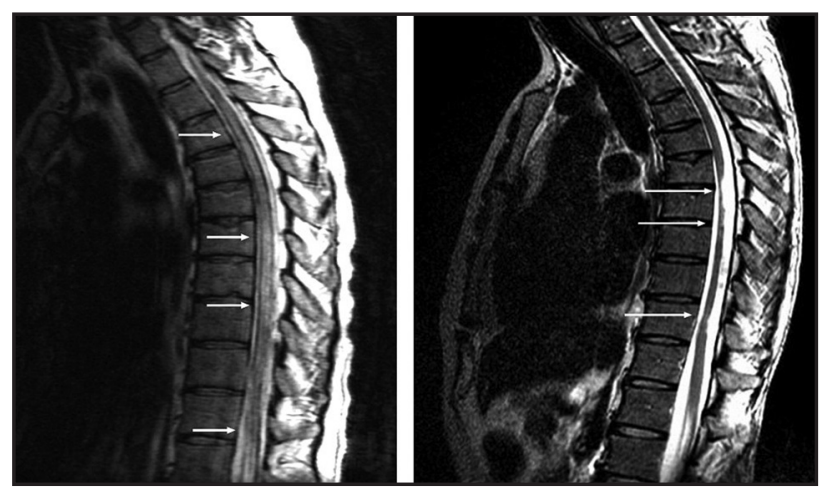

FIGURE 3

Magnetic resonance imaging: a T2-weighted image of the spinal cord before (on the left - hyperintensity of signal - arrows) and one year after treatment (on the right - thinning of the spinal cord - arrows).

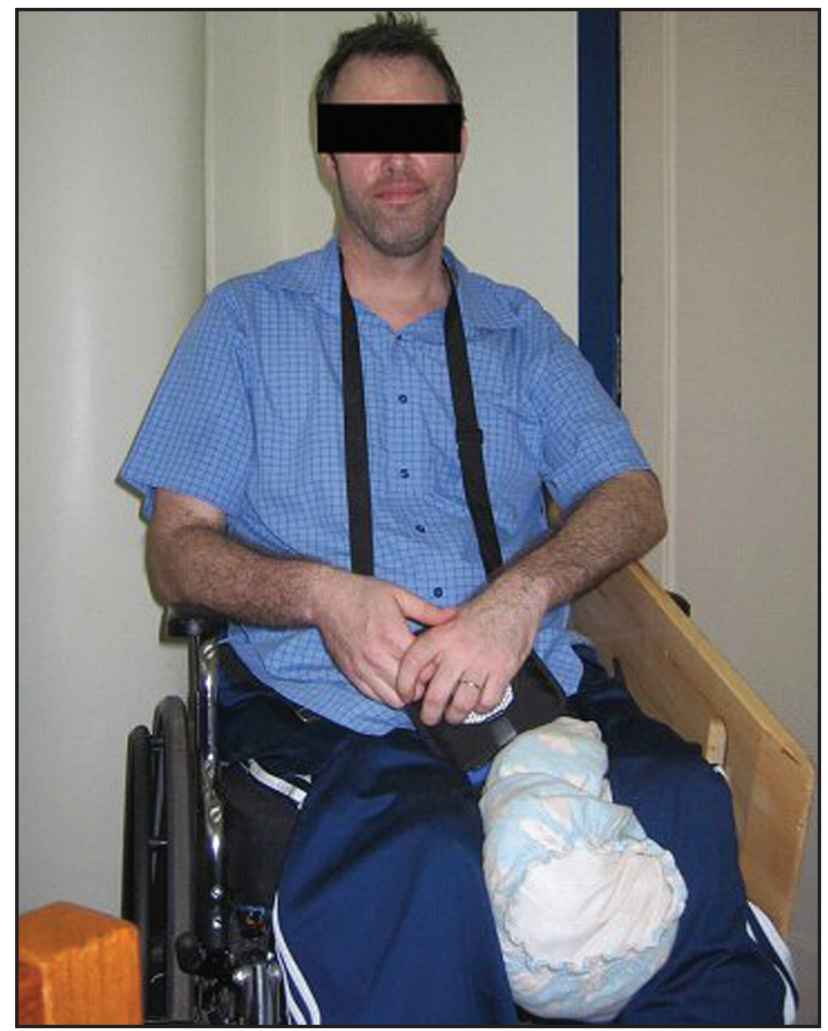

FIGURE 4

The patient one year after diagnosis of schistosomal brain tumor and myeloradiculopathy.

\section{DISCUSSION}

In the case presented here, the patient reported sudden paraplegia three weeks after being diagnosed with a brain tumor caused by Schistosoma mansoni infection. He was treated with praziquantel twice, the first time during his hospitalization in Puerto Rico and the second time, in the United States. One year later, the patient presented no signs of the brain lesion but was found to have spinal cord atrophy.

As far as we know, this is the first documented case of simultaneous brain and spinal cord involvement diagnosed by magnetic resonance imaging and brain biopsy and followed up for at least one year after diagnosis and treatment.

The case reported by Ruffino et $\mathrm{al}^{28}$ was of a 25 -year-old woman from Martinique. She was diagnosed as having encephalitis followed by flaccid paraplegia while she was still in the hospital, suggesting spinal cord involvement due to the same infectious agent. The diagnosis of schistosomiasis was confirmed by findings of Schistosoma mansoni eggs in the stools, and the final diagnosis was based on the excellent response to treatment with a schistosomicide, used in those days, named niridazole. This is interesting because it shows that, even with the use of a schistosomicide alone, there may be improvement in the neurological disease caused by Schistosoma mansoni.

The case reported by Artal et $\mathrm{al}^{2}$ was of a 65-year-old man from Brazil. This case is curious because the disease started with progressive paresis in the lower limbs, urinary and fecal dysfunction, pain and tingling in lumbosacral dermatomes. This patient was treated with steroids and improved greatly, only to reappear six months later, with several tonic-clonic partial seizures. Magnetic resonance imaging of the spinal cord showed swelling of the lower thoracic spinal cord and conus medullaris, while magnetic resonance imaging of the brain revealed hyperintense areas in the left frontal-parietal white matter. Brain biopsy confirmed the schistosomal infection. He was treated with praziquantel and dexamethasone but no improvement of the hemiparesis was observed during follow-up. The opposite was observed in our patient: he first developed a brain tumor and later on, the spinal cord injury. There was total reversal of the brain lesion but no improvement of the spinal cord manifestations.

The simultaneous occurrence of brain and spinal cord involvement in schistosomiasis cases implies that worms or eggs of Schistosoma mansoni were present in the spinal cord and in the brain ${ }^{519}$. Alternatively, it implies that schistosomes migrated to the brain or spinal cord after treatment was started. It is possible that the anesthetic used in the surgical procedure (brain biopsy) may have dislodged the worms from their usual habitat ${ }^{7}$. Another hypothesis is that cerebral vasculitis may appear after treating schistosomiasis with praziquantel, as has been reported by Jauréguiberry et $\mathrm{al}^{8}$ in a patient with acute neuroschistosomiasis. However, in the case of our patient, it is difficult to choose an explanation for the spinal cord involvement. No biopsy of the spinal cord to confirm the presence of Schistosoma mansoni eggs $^{30}$ was available and hence associated vasculitis cannot be ruled out ${ }^{33}$. It is worth mentioning that there was extensive involvement of 
the spinal cord in the case presented here (the lesion extended from T1 to T11, as documented by magnetic resonance imaging), which was followed by severe spinal cord atrophy ${ }^{25}$.

With regard to different responses to treatments for neuroschistosomiasis, it is common knowledge that the sooner the treatment is started, the better the response that can be expected. The other point is that treatment should be kept up for at least two months. We were able to document improvements, particularly regarding urinary symptoms and sexual dysfunction, for up to six months after starting on steroids ${ }^{32}$. In the case of our patient, we believe that treatment with steroids was halted too early within the course of the spinal cord involvement. Steroids should be given for at least two months, in order to be sure that the best treatment is being administered.

In conclusion, we have presented the case of a young male patient with simultaneous brain and spinal cord involvement caused by Schistosoma mansoni. The reason for the association is not known. This patient responded well to treatment of the brain lesion, but was left with permanent paraplegia due to spinal cord atrophy. This patient may be a good candidate for transfer of pluripotent stem cells to the spinal cord.

\section{REFERENCES}

1. Andrade Filho AS, Reis MG, Souza AL, Martins ER, Santos SRS, Ancilon M, Lima JMPF, Queiroz AC, Guimarães MGM, Moreno-Carvalho A0, Rêgo MF. Neuroesquistossomose mansônica: aspectos clínicos, laboratoriais e terapêuticos. Arquivos de Neuropsiquiatria 54: 232-237, 1996.

2. Artal FJC, Mesquita HM, Gepp RA, Antunes JS, Kalil RK. Brain involvement in a Schistosoma mansoni myelopathy patient. Journal of Neurology Neurosurgery and Psychiatry 77: 512, 2005.

3. Artal FJC, Vargas AP, Horan TA, Marinho PB, Coelho-Costa PH. Schistosoma mansoni myelopathy: clinical and pathologic findings. Neurology 63: 388-391, 2004.

4. Bambirra EA, Andrade JS, Cesarini, I, Rodrigues PA, Drummond CA. The tumoral form of schistosomiasis: report of a case with cerebellar involvement. American Journal of Tropical Medicine and Hygiene 33: 76-79, 1984.

5. Barros MO, Giannoni FG, Marigo C, Frizzo FJ. Cor pulmonale e miocardite esquistossomóticos: considerações clínico-patológicas a propósito de dois casos. Arquivos do Hospital da Santa Casa de São Paulo 2: 33-72, 1956.

6. Braga, BP, Costa Junior LB, Lambertucci JR. Magnetic resonance imaging of cerebellar schistosomiasis mansoni. Revista da Sociedade Brasileira de Medicina Tropical 36: 635-636, 2003.

7. Cunha-Melo JR, Coelho PM. Schistosoma mansoni: effects of anesthetics and antimonial drugs on worm shift in the mouse. Revista do Instituto de Medicina Tropical de São Paulo 28:267-270, 1986.

8. Drummond SC, Silva LC, Amaral RS, Sousa-Pereira SR, Antunes CM, Lambertucci JR. Morbidity of schistosomiasis mansoni in the state of Minas Gerais, Brazil. Memórias do Instituto Oswaldo Cruz 101: 37-44, 2006.

9. Jaréguiberry S, Ansart S, Perez L, Danis M, Bricaire F, Caumes E. Acute neuroschistosomiasis: two cases associated with cerebral vasculitis. American Journal of Tropical Medicine and Hygiene 76: 964-966, 2007.

10. Kane C, Most H. Schistosomiasis of the central nervous system. Archives of Neurology and Psychiatry 59: 141-183, 1948.

11. Lambertucci JR. Schistosoma mansoni: pathological and clinical aspects. In: Jordan $\mathrm{P}$, Webbe $\mathrm{G}$ (eds) Human Schistosomiasis. Cab International, Wallingford, Oxon, UK, p. 195-235, 1993.
12. Lambertucci JR, Rocha RS, Carvalho OS, Katz N. A esquistossomose mansoni em Minas Gerais. Revista da Sociedade Brasileira de Medicina Tropical 20: 47-52, 1987.

13. Lambertucci JR, Serufo JC, Gerspacher-Lara R, Rayes AAM, Teixeira R, Nobre V, Antunes CMF. Schistosoma mansoni: assessment of morbidity before and after control. Acta Tropica 77: 101-109, 2000.

14. Lambertucci JR, Silva LCS, Amaral RS. Guidelines for the diagnosis and treatment of schistosomal myeloradiculopathy. Revista da Sociedade Brasileira de Medicina Tropical 40: 574-581, 2007.

15. Lambertucci JR, Silva LCS, Andrade LM, Queiroz LC, Carvalho VT, Voieta I, Antunes CM. Imaging techniques in the evaluation of morbidity in schistosomiasis mansoni. Acta Tropica 108: 209-217, 2008.

16. Lambertucci JR, Sousa-Pereira SR, Silva LC. Myeloradiculopathy in acute schistosomiasis mansoni. Revista da Sociedade Brasileira de Medicina Tropical 38: $277-278,2005$.

17. Lambertucci JR, Teixeira R, Navarro MM, Coelho PMZ, Ferreira MD. Liver abscess and schistosomiasis. A new association. Revista da Sociedade Brasileira de Medicina Tropical 23: 239-240, 1990.

18. Lambertucci JR, Voieta I, Silveira IS. Cerebral schistosomiasis mansoni. Revista da Sociedade Brasileira de Medicina Tropical 41: 693-694, 2008.

19. Marcial-Rojas R, Fiol R. Neurologic complications of schistosomiasis. Annals of Internal Medicine 59: 521-525, 1963.

20. Naus CW, Chipwete JJ, Visser LG, Zijlstra EE, van Lieshout L. The contribution made by Schistosoma infection to non-traumatic disorders of the spinal cord in Malawi. Annals of Tropical Medicine and Parasitology 97: 711-721, 2003.

21. Nobre V, Silva LCS, Ribas JG, Rayes A, Serufo JC, Lana-Peixoto MA, Marinho RFZ, Lambertucci JR. Schistosomal myeloradiculopathy due to Schistosoma mansoni: report on 23 cases. Memórias do Instituto Oswaldo Cruz 96: 137-141, 2001.

22. Peregrino AJP, Puglia PMK, Nóbrega JPS, Livramento JA, Marques-Dias MJ, Scaff M. Esquistossomose medular: Análise de 80 casos. Arquivos de Neuropsiquiatria 60: 603-608, 2002.

23. Pitella JEH. The relation between involvement of the central nervous system in schistosomiasis mansoni and the clinical forms of the parasitosis. A review. Journal of Tropical Medicine and Hygiene 94: 15-21, 1991.

24. Pitella JEH. Neuroschistosomiasis. Brain Pathology 7: 649-662, 1997.

25. Queiroz LS, Nucci A, Facure NO, Facure JJ. Massive spinal cord necrosis in schistosomiasis. Archives of Neurology 36: 517-519, 1979.

26. Raso P, Tafuri A, Lopes NF, Monteiro ER, Tafuri WL. The tumoral form of cerebellar schistosomiasis: case report and measure of granulomas. Revista da Sociedade Brasileira de Medicina Tropical 39: 283-286, 2006.

27. Roberts M, Cross J, Pohl U, Lucas S, Dean A. Cerebral schistosomiasis. Lancet Infectious Diseases 6: 820, 2006.

28. Ruffino J, Masson, M, Lange J, Lesobre R. Schistosomiase mansoni a localisation nerveuse avec atteinte cérébrale et médullaire. Presse Medicale 78: 1517-1518, 1970.

29. Scrimgeour EM, Gajduzek DC. Involvement of the central nervous system in Schistosoma mansoni and Schistosoma haematobium infection: a review. Brain 108: 1023-1038, 1985.

30. Silva LCS, Kill CM, Lambertucci JR. Cervical spinal cord schistosomiasis. Revista da Sociedade Brasileira de Medicina Tropical 35: 543-544, 2002.

31. Silva LCS, Maciel PE, Ribas JG, Pereira SR, Serufo JC, Andrade LM, Antunes CM, Lambertucci JR 2004. Schistosomal myeloradiculopathy. Revista da Sociedade Brasileira de Medicina Tropical 37: 261-272, 2004.

32. Silva LCS, Maciel PE, Ribas JGR, Sousa-Pereira SR, Antunes CM, Lambertucci JR. Treatment of schistosomal myeloradiculopathy with praziquantel and corticosteroids and evaluation by magnetic resonance imaging: a longitudinal study. Clinical Infectious Disease 39: 1618-1624, 2004.

33. Sousa-Pereira SR, Teixeira AL, Silva LC, Souza AL, Antunes CM, Teixeira MM, Lambertucci JR 2006. Serum and cerebral spinal fluid levels of chemokines and Th2 cytokines in Schistosoma mansoni myeloradiculopathy. Parasite Immunology 28: 473-478, 2006. 